\title{
Novel autoantibodies and clinical phenotypes in adult and juvenile myositis
}

\author{
Zoe E Betteridge*, Harsha Gunawardena and Neil J McHugh
}

\begin{abstract}
Autoantibodies targeting intracellular proteins involved in key processes are detected in patients with idiopathic inflammatory myopathies. These myositisspecific autoantibodies have been increasingly demonstrated to correlate with distinct clinical phenotypes within the myositis spectrum. This review highlights the clinical associations of the myositisspecific autoantibodies, with particular attention to the recently identified and characterized novel myositis autoantibodies: p155/140, p140 (MJ), CADM-140 (MDA5), SAE, and 200/100.
\end{abstract}

\section{Introduction}

The idiopathic inflammatory myopathies (IIMs) polymyositis (PM) and dermatomyositis (DM) are heterogeneous conditions that are historically diagnosed by proximal muscle weakness, evidence of muscle inflammation or necrosis, and characteristic skin lesions $[1,2]$. However, it is now well recognized that patients can present with other overlapping features, including arthritis and systemic involvement (including interstitial lung disease, or ILD), and this has led to the proposal of alternative diagnostic criteria [3]. In recent years, it has become even more apparent that autoantibodies have a role in distinguishing between further subtypes of myositis patients, and clinico-serological classifications have been proposed. The myositis autoantibodies can be divided into myositis-associated autoantibodies (MAAs) and myositis-specific autoantibodies (MSAs). The MAAs - anti-PMScl, anti-Ku, anti-U1RNP, and antiU3RNP (fibrillarin) - are commonly found in myositis patients who have features of other connective tissue diseases (CTDs) (in particular, overlap with systemic sclerosis). In contrast, the MSAs are found exclusively in

*Correspondence: prpzeb@bath.ac.uk

Royal National Hospital for Rheumatic Diseases, NHS Foundation Trust, Upper Borough Walls, Bath, Somerset, BA1 1RL, UK
IIM and are directed to specific proteins found in both the nuclear and cytoplasmic regions of the cell; these MSAs correlate with genotype and clinical manifestations $[4,5]$. Investigations into these specific autoantibodies help classify myositis patients into increasingly homogeneous subgroups, may guide specific treatment regimes, and importantly increase our understanding of the pathogenesis of IIM.

The 'traditional' MSAs - anti-Jo-1 (and the less common non-Jo-1 anti-synthetases), anti-SRP, and anti$\mathrm{Mi}-2$ - can be detected by routine commercial assays and are identified in approximately $40 \%$ to $50 \%$ of adult myositis patients and in less than $10 \%$ of juvenile dermatomyositis (JDM) patients [6]. More recently, a number of groups have reported the identification of novel MSAs, including anti-p155/140, anti-SAE, antiCADM-140 (melanoma differentiation-associated gene 5, or MDA5), anti-p140, and anti-200/100, the clinical and genetic associations of which are described in this review. With the inclusion of the latter MSAs, it is now possible to identify a positive MAA or MSA in approximately $80 \%$ of myositis patients, allowing a clearer serological stratification of patients (Table 1 and Figure 1).

\section{Anti-synthease syndrome}

Anti-synthetase autoantibodies

The most prevalent group of MSAs consists of the antisynthetase autoantibodies. These autoantibodies target the amino-acyl-tRNA synthetases (ARSs) which catalyze the binding of amino acids to the corresponding tRNAs. Each amino acid has a separate ARS, and autoantibodies targeting 8 of the 20 ARSs have been identified. The most common of these is anti-Jo-1 (anti-histidyl tRNA synthetase), which is found in approximately $20 \%$ of adult IIM patients. The remaining anti-synthetases - PL-12 (alanyl), PL-7 (threonyl), EJ (glycyl), OJ (isoleucyl), KS (asparginyl), and the more recently identified Ha (tyrosyl) and Zo (phenylalanyl) - have been collectively described in a further $20 \%$ of patients, and the frequency of each individual autoantibody is between $1 \%$ and $5 \%$ [4]. In contrast, the prevalence of ASAs in juvenile myositis patients is much lower: less than 3\% [7]. With a few exceptions, each ASA-positive patient develops 
Table 1. Myositis-specific autoantibodies, target autoantigens, and clinical associations

\begin{tabular}{|c|c|c|c|c|}
\hline \multirow[b]{2}{*}{ Autoantibody } & \multirow[b]{2}{*}{ Target autoantigen } & \multirow[b]{2}{*}{ Clinical associations } & \multicolumn{2}{|c|}{ Frequency, percentage } \\
\hline & & & Adults & JDM \\
\hline Anti-ARS & Amino-acyl-tRNA synthetase & Anti-synthetase syndrome & Overall: 30-40 & Overall: 1-3 \\
\hline- Jo-1 & - Histidyl & Myositis & Jo-1: 15-20 & \\
\hline - PL7 & - Theronyl & Interstitial lung disease & PL7: $<5$ & \\
\hline - PL12 & - Alanyl & Raynaud phenomenon & PL12: $<5$ & \\
\hline- OJ & - |soleucy| & Arthritis & OJ: $<5$ & \\
\hline$-E J$ & - Glycyl & Mechanic's hands & $E J:<5$ & \\
\hline$-\mathrm{KS}$ & - Asparaginyl & Fever & $\mathrm{KS}:<5$ & \\
\hline$-\mathrm{Ha}$ & -Tyrosyl & & $\mathrm{Ha}:<1$ & \\
\hline - Zo & - Phenylalanyl & & Zo: $<1$ & \\
\hline Anti-Mi-2 & $\begin{array}{l}\text { Nucleosome remodeling deacetyalse } \\
\text { complex (NuRD) }\end{array}$ & DM & $<10$ & $4-10$ \\
\hline \multirow[t]{2}{*}{ Anti-p155/140 } & \multirow{2}{*}{$\begin{array}{l}\text { Transcriptional intermediary factor } 1 \\
\text { gamma (TIF1- } \gamma)\end{array}$} & JDM: DM and ulceration & $13-21$ & $22-29$ \\
\hline & & Adults: DM and malignancy & & \\
\hline \multirow[t]{2}{*}{ Anti-p140 } & \multirow[t]{2}{*}{ Nuclear matrix protein 2 (NXP2) } & JDM: DM and calcinosis & $<5$ & 23 \\
\hline & & Adults: DM and ILD & & \\
\hline Anti-SAE & $\begin{array}{l}\text { Small ubiquitin-like modifier activating } \\
\text { enzyme (SAE) }\end{array}$ & DM & $<5$ & $<1$ \\
\hline Anti-CADM-140 & $\begin{array}{l}\text { Melanoma differentiation-associated } \\
\text { gene } 5 \text { (MDA5) }\end{array}$ & CADM and ILD & 50-73 CADM (not in Caucasians) & Not known \\
\hline Anti-SRP & Signal recognition particle (SRP) & Necrotizing myopathy & $5-10$ & $<3$ \\
\hline Anti-200/100 & Unknown 100- and 200-kDa proteins & Necrotizing myopathy & $<10$ necrotizing myopathy & Not known \\
\hline
\end{tabular}

ARS, amino-acyl-tRNA synthetase; CADM, clinically amyopathic dermatomyositis; DM, dermatomyositis; ILD, interstitial lung disease; JDM, juvenile dermatomyositis.

autoantibodies to only a single ARS. Patients with these autoantibodies are classed as having the anti-synthetase syndrome (ASS) with clinical associations of myositis, ILD, non-erosive arthritis, mechanic's hands, Raynaud phenomenon, and fever, and some patients also have a DM rash.

The presence of an ASA has also been shown to indicate response to corticosteroid treatment, particularly in the context of ILD, with ASA-positive patients responding better to initial therapy but having relapses more frequently than ASA-negative patients [8]. Furthermore, it has been demonstrated that titers of anti-Jo-1 autoantibodies moderately correlate with serum creatine kinase levels as well as joint and muscle disease activity [9], demonstrating that the presence and titer of MSAs can help predict disease course and treatment response.

Recently, it has been shown that, while the ASS covers all eight anti-synthetase autoantibodies, the precise clinical manifestations associated with each autoantibody are not identical. It has been reported that anti-Jo-1 autoantibodies are closely associated with what would be classically described as PM, with the majority developing clinically significant myositis over the full disease course [10]. In comparison, anti-OJ, anti-KS, and anti-PL-12 have been more closely associated with DM skin lesions and are strongly associated with ILD. The development of clinically evident myositis in these patients is less frequent than with anti-Jo-1 and often occurs after the onset of ILD [11-13]. In addition, patients with anti-PL-7 may have lower serum muscle enzyme levels and milder muscle weakness in comparison with anti-Jo-1 patients [14].

Anti-Ha, the seventh ASA to be identified, was identified by means of a combination of immunoaffinity purification and mass spectrometry. So far, it has been demonstrated in only one patient who displayed clinical manifestations of ILD and myositis [15]. Anti-Zo, the most recent ASA to be identified, was identified by means of immunoprecipitation (IPP) and mass spectrometry. It was first detected in an index case with myositis and ILD [16] and has since been found in a further three patients with classic ASS features (ZEB and NJM, unpublished data).

Further studies have been completed on the pathogenic roles of the ASAs and their corresponding autoantigens. Seminal work by Casciola-Rosen and colleagues [17] has shown that Jo-1 autoantigen expression is enhanced in the muscle of myositis patients in comparison with normal controls, suggesting a role for autoantigens in the 


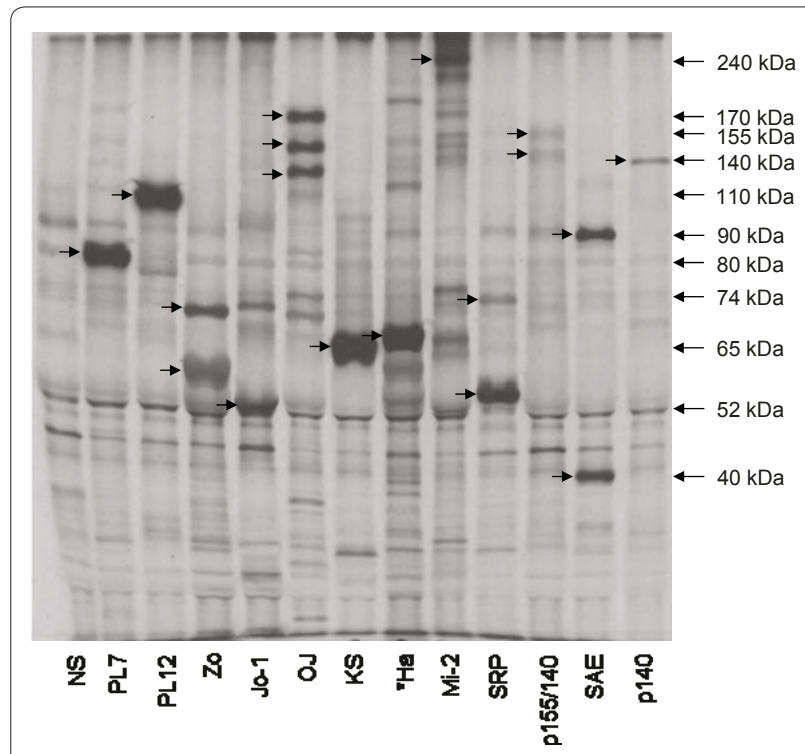

Figure 1. Immunoprecipitation of myositis-specific

autoantibodies. Ten percent SDS-PAGE of immunoprecipitates of [35S] labeled K562 cell extract. Lane 1: normal serum; lane 2: antiPL7; lane 3: anti-PL12; lane 4: anti-Zo; lane 5: anti-Jo-1; lane 6: antiOJ; lane 7: anti-KS; lane 8: anti Ha (unconfirmed); lane 9: anti-Mi-2; lane 10: anti-SRP; lane 11: anti-p155/140 (TIF1-ү); lane 12: anti-SAE; and lane 13: anti-p140 (NXP2). Myositis-specific autoantibodies not shown include anti-EJ, anti p100/200, and anti-CADM-140 (MDA5). CADM, clinically amyopathic dermatomyositis; MDA5, melanoma differentiation-associated gene 5; NXP2, nuclear matrix protein 2; SAE, small ubiquitin-like modifier activating enzyme 1 and 2; SRP, signal recognition particle; TIF1- $\gamma$, transcription intermediary factor 1 gamma.

pathogenesis of IIM. This group has shown that certain ARSs can be cleaved by granzyme B which may reveal autoantigenic epitopes [18], and Levine and colleagues [19] demonstrated that the cleavable conformation of Jo-1 is found predominantly in alvelolar cells, suggesting that the lung microenvironment is the site of disease initiation in the Jo-1 syndrome. Further work has shown that Jo-1, KS, and Ha autoantigens have chemoattractant properties and can induce leukocyte migration, hence potentially propagating the immune response [20]. A study by Barbasso Helmers and colleagues [21] demonstrated that serum from anti-Jo-1-positive patients had a significantly stronger effect on the expression of intercellular adhesion molecule 1 (ICAM-1) in human microvascular endothelial cell (HMVEC) lung tissue in comparison with serum from healthy controls or patients with other autoantibodies. Endothelial cell activation by increased ICAM-1 expression may contribute to the multiorgan involvement of myositis and ILD in anti-Jo-1positive patients [21]. Finally, in vitro studies demonstrating the potential for anti-Jo-1 autoantibodies to induce type 1 interferon may suggest a direct pathogenic role in disease propagation [22].

\section{Dermatomyositis clinical phenotypes}

\section{Anti-Mi-2}

Targoff and Reichlin [23] first described anti-Mi-2 autoantibodies in $9 \%$ of adult myositis patients and more specifically in $20 \%$ of adult DM patients. Subsequent studies on JDM cohorts have shown that anti-Mi-2 may also occur albeit at a lower frequency (4\% to $10 \%$ ) $[7,24,25]$. This autoantibody has been associated with hallmark cutaneous DM lesions, including Gottron papules, heliotrope rash, cuticular overgrowth, and Vsign and Shawl sign rashes. Love and colleagues [26] reported a correlation between UV radiation exposure at myositis onset and the development of anti-Mi-2 autoantibodies, suggesting an influence of environmental features on the development of autoimmunity in this syndrome. Interestingly, in vitro studies have demonstrated that the Mi-2 protein is upregulated in UV-irradiated human keratinocytes, further highlighting potential disease mechanisms [27]. The autoantigen target, Mi-2, is a nuclear helicase protein that forms part of the nucleosome-remodeling deacetylase complex, which plays a role in gene transcription [28]. In work similar to studies on Jo-1 expression in target tissues, Mi-2 has been shown to be overexpressed in myositis muscle compared with normal muscle and in particular is upregulated in human DM myofibers expressing markers of regeneration $[17,29]$. Functionally, Mi-2 has been shown to be essential for the repair of skin basal epidermis [30]; collectively, these data indicate that the autoantigen may have a role in the pathogenesis of disease.

\section{Anti-p155/140 (TIF1- $ү$ )}

Autoantibodies to a $155-\mathrm{kDa}$ protein (in most cases with a weaker $140-\mathrm{kDa}$ band) and a $155-\mathrm{kDa} / 140-\mathrm{kDa}$ complex were first reported by Targoff and colleagues [31] and Kaji and colleagues [32]. Targoff and colleagues screened a cohort of 244 North American patients with IIM and found anti-p155/140 in $21 \%$ of the patients. Investigations into the clinical features of the antip155/140-positive patients showed an association with $\mathrm{DM}$ and cancer and also demonstrated that Caucasian patients with anti-p155/140 autoantibodies had a unique HLA risk factor: DQA1"0301. The parallel study by Kaji and colleagues screened 52 Japanese patients with DM along with healthy controls and disease controls. The study found anti-p155/140 autoantibodies exclusively in $13 \%$ of patients with DM. Clinical manifestations of the p155/140-positive DM patients, including the significant association with malignancy as well as a more severe DM skin disease, were similar to those noted in the study by Targoff and colleagues. The strong link with cancerassociated myositis was confirmed in a larger cohort study of Caucasian adult patients from the UK (Adult Onset Myositis Immunogenetic Collaboration [AOMIC] 
study group) [33]. In a recent review, Selva-O'Callaghan and colleagues [34] performed a meta-analysis of all published anti-p155/140 cohort studies to determine the accuracy of anti-p155/140 autoantibodies for predicting cancer in DM. Overall, anti-p155/140 autoantibodies have an $89 \%$ specificity and a $70 \%$ sensitivity for predicting malignancy and have a negative predictive value of $93 \%$ and a diagnostic odds ratio of 18 [34].

Studies investigating the occurrence of anti-p155/140 autoantibodies in JDM patients have also been completed. Gunawardena and colleagues [35] screened 116 JDM cases by radiolabeled IPP and found anti-p155/140 autoantibodies in $23 \%$ of the patients. Similarly, both Espada and colleagues [36] and Targoff and colleagues [31] have detected anti-p155/140 in $22 \%$ and $29 \%$ of patients with JDM, respectively. Interestingly, while the antip155/140 autoantibody has been demonstrated by radiolabeled immunodepletion experiments to target the same autoantigens as the adult anti-p155/140 autoantibody, there are some clinical differences. In particular, cancer was not associated with anti-155/140-positive JDM cases; however, both anti-p155/140-positive adults and children appear to have a more severe cutaneous disease [35].

In preliminary work, the $155-\mathrm{kDa}$ autoantigen target was identified by immunoaffinity purification and mass spectrometry as transcription intermediary factor 1 gamma (TIF1- $\gamma$ ). This was confirmed by immunization of rabbits with a TIF1- $\gamma$ peptide with affinity purification of subsequent antibodies for use in sandwich enzymelinked immunosorbent assays (ELISAs) [37]. The identity of the autoantigen detected as the associated $140-\mathrm{kDa}$ band has yet to be established, although this is likely to be a degradation product of TIF1- $\gamma$ or possibly TIF1- $\alpha$, an isoform that has a molecular weight of $140 \mathrm{kDa}$. TIF1- $\gamma$ is a nuclear protein involved in controlling DNA transcription. Moreover, TIF1- $\gamma$ has been shown to inactivate Smad-4, which regulates transforming growth factorbeta (TGF- $\beta$ ) signaling, thus promoting cell growth and differentiation (including malignant tumors) [38].

More recently, Hoshino and colleagues [39] developed a non-radiolabeled method for screening CTD patients for the presence of anti-p155/140. Biotinylated recombinant TIF1- $\gamma$ was produced from a cDNA vector and used as the antigen source in a non-radiolabeled IPP assay. Comparisons between the results of this screen and standard radiolabeled IPP using HeLa cell lysates were similar, with $10 \mathrm{DM}$ patients being positive in both assays, $68 \mathrm{DM}$ patients being negative in both assays, and 5 DM patients being positive in only one assay. The authors suggested that the differences in results between the two assays might have been due to differences in conformation, protein stability, or other factors of the autoantigens. Interestingly, while the biotinylated assay may not have been as sensitive for the detection of weakly reactive anti-TIF1- $\gamma$ autoantibodies, the detection of anti-TIF1- $\gamma$ in cancer-associated DM was not reduced. The introduction of this novel, non-radiolabeled assay may therefore be extremely helpful in the setting of routine laboratories for the screening of DM patients [39].

\section{Anti-CADM-140 (MDA5)}

Autoantibodies to a $140-\mathrm{kDa}$ cytoplasmic protein in Japanese adult patients with clinically amyopathic dermatomyositis (CADM) were first described by Sato and colleagues [40]. This novel autoantibody was shown to be associated with rapidly progressive ILD. Further investigation in Asian adult cohorts of CTD patients has shown anti-CADM-140 to be specific for DM, with most having CADM [39,41,42]. Furthermore, anti-CADM-140 has been associated with elevated serum ferritin concentrations, suggesting an association of anti-CADM-140 and macrophage activation syndrome. Patients with CADM-140 autoantibodies have also been shown to have a poor prognosis; one study demonstrated that $46 \%$ of anti-CADM-140-positive patients died of respiratory failure within 6 months of disease onset [42].

Studies investigating p155/140 autoantibodies, antiCADM-140 autoantibodies, and anti-synthetase autoantibodies have shown that these autoantibodies are mutually exclusive [43]. Interestingly, while studies have shown that the incidence of ILD in CADM is greater in Asia, a systematic review of patients in North America and Europe has shown that approximately $15 \%$ of CADM patients develop ILD. The prevalence of anti-CADM-140 has been reported to be between $19 \%$ and $35 \%$ in Japanese patients with DM and between $53 \%$ and $73 \%$ in Japanese patients with CADM; however, to date, this autoantibody has not been described in European or American Caucasian cohorts, implying that either a genetic or an environmental factor is associated with anti-CADM-140 generation.

The CADM-140 autoantigen has been identified as MDA5 from a cDNA expression library [41]. This protein is one of the retinoic acid-inducible gene-1-like receptors and has a role in the recognition of viral RNAs as part of the innate immune system. The identification of this autoantigen may therefore provide insight into the pathogenesis of CADM and ILD and into the reported association between viral infections and myositis. The clinical utility and identity of this autoantigen have since been confirmed in further studies by a combination of immunoaffinity chromatography with mass spectrometry analysis, by immunoblot with a commercial antibody, and by IPP with a biotinylated recombinant MDA5 protein $[39,42]$.

\section{Anti-p140 or anti-MJ (NXP-2)}

A different $140-\mathrm{kDa}$ autoantigen target has also been described in DM patients. This autoantibody was originally 
termed anti-MJ and was found in $18 \%$ of 80 American patients with JDM [44]. In a preliminary study by Targoff and colleagues [45], the MJ autoantigen was identified as NXP2 (nuclear matrix protein 2, also known as MORC3) by means of a K562 cDNA expression library. This protein is involved in transcriptional regulation [46]. Gunawardena and colleagues [47] demonstrated that anti-p140 autoantibodies are a major serological subset in children recruited to the UK JDM Cohort Study. After IPP studies, $23 \%$ of 162 children were anti-p140-positive and had a higher incidence of calcinosis. Immunodepletion experiments using a commercial anti-NXP2 antibody suggested that the p140 target in this study has the same identity as the MJ autoantigen. Recently, antiMJ was also described in 25\% of an Argentinean juvenile IIM cohort and was associated with muscle contractures, atrophy, and significant compromise of functional status [36]. Parallel studies on the European adult IIM cohort study (EuMyoNet) have also demonstrated the presence of what appears to be the same anti-p140 specificity, which was found exclusively in 5\% of DM patients. Preliminary data suggest that the clinical associations in adults differ from JDM, with anti-p140 autoantibodies being associated with ILD in adults [48].

\section{Anti-SAE}

Betteridge and colleagues [49] first described the presence of novel autoantibodies targeting 40-kDa and 90-kDa proteins in DM patients with similar clinical manifestations. Using IPP and mass spectrometry, the authors identified these proteins as small ubiquitin-like modifier activating enzyme 1 and 2 (SAE) that are involved in the post-translational modification of numerous targets, including protein kinases and transcription factors [49]. Further work has confirmed that anti-SAE was found in $8 \%$ of DM patients from the AOMIC UK study. The majority of anti-SAE patients presented with cutaneous manifestations and progressed to myositis with systemic features, including dysphagia. This autoantibody was associated with a low frequency of malignancy and ILD. Furthermore, genetic studies found a strong association of the anti-SAE autoantibody with the HLA-DRB1*04 DQA1"03 DQB1"03 haplotype [50]. This autoantibody has also been investigated in the UK JDM Cohort and, with the exception of one patient, has not been seen in JDM (HG and ZEB, unpublished data).

\section{Immune-mediated necrotizing myopathy Anti-signal recognition particle}

Autoantibodies to the signal recognition particle (SRP) were first demonstrated in IIM by Reeves and colleagues [51]. SRP is a cytoplasmic protein with a role in the recognition and translocation of newly synthesized proteins across the endoplasmic reticulum. Anti-SRP autoantibodies are present in approximately $5 \%$ of adult myositis patients and have been associated with acuteonset severe necrotizing myopathy and with systemic features that may be refractory to standard immunomodulatory treatments [52-54]. Muscle biopsies from anti-SRP patients classically demonstrate muscle fiber necrosis with minimal inflammatory cell infiltrate [5355]. Conversely, anti-SRP autoantibodies are rarely detected in juvenile patients. A study by Rouster-Stevens and colleagues [56] detected anti-SRP in 3 of 123 children with clinical manifestations similar to those of anti-SRP adult patients. Interestingly, all of the anti-SRP-positive cases were of African-American origin, suggesting a specific immunogenetic association [56].

\section{Anti-200/100}

The most recent myositis autoantibody to be described, by Christopher-Stine and colleagues [57], is the anti200/100 autoantibody. Muscle biopsies from 225 myositis patients were screened for necrotizing myopathy features. Thirty-eight patients demonstrated predominant necrosis without histological findings of perifascicular atrophy or red-rimmed vacuoles, and 26 of these patients had no known MSA. After radiolabeled IPP using HeLa cells, $16(62 \%)$ of these MSA-negative patients were found to immunoprecipitate $200-\mathrm{kDa}$ and $100-\mathrm{kDa}$ proteins. Since both of these proteins were immunoprecipitated together in all cases, the authors suggested that the subunits are likely to be part of the same protein complex. This pattern was found in only one patient (from 187) without necrosis and in no healthy controls, indicating that this novel autoantibody is associated with immune-mediated necrotizing myopathy. Interestingly, $63 \%$ of patients with this autoantibody were found to have a history of exposure to statins. Further studies now need to be completed, identifying the $200 / 100-k D a$ doublet, assessing the frequency of this autoantibody in additional cohorts, and clarifying the potential association of this autoantibody with statin exposure.

\section{Conclusions}

In this review, we have highlighted the recent studies identifying and characterizing novel myositis autoantibodies and their associated autoantigens. The increasing number of patients with a known MSA aids the clinicoserological classification of myositis and may help to predict complications of disease, prognosis, and responses to treatment. The identification of these novel autoantibodies has lead to an increasing demand for the development of commercial assays in order to allow the screening of patients in the routine clinical setting. The recent development and validation of a line blot assay containing a number of the MSAs demonstrate 
progression in this field [58,59] and further work is currently in progress. Studies of MSAs and their corresponding targets have also provided insights into the pathogenesis of IIM, and links between environmental, immunogenetic, and autoantibody status have been described. Further studies are now required to identify novel targets in patients who are currently viewed as autoantibody-negative and to further elucidate the role of autoimmunity in the pathophysiology of IIM subtypes.

Autoimmune Basis of Rheumatic Diseases

This article is part of a series on Myositis, edited by Ingrid Lundberg, which can be found online at

http://arthritis-research.com/series/myositis

This series forms part of a special collection of reviews covering major autoimmune rheumatic diseases, available at:

http://arthritis-research.com/series/abrd

\section{Abbreviations}

AOMIC, Adult Onset Myositis Immunogenetic Collaboration; ARS, amino-acyltRNA synthetase; ASS, anti-synthetase syndrome; CADM, clinically amyopathic dermatomyositis; CTD, connective tissue disease; DM, dermatomyositis; ICAM1, intercellular adhesion molecule 1; IIM, idiopathic inflammatory myopathy; ILD, interstitial lung disease; IPP, immunoprecipitation; JDM, juvenile dermatomyositis; MAA, myositis-associated autoantibody; MDA5, melanoma differentiation-associated gene 5; MSA, myositis-specific autoantibody; PM, polymyositis; SAE, small ubiquitin-like modifier activating enzyme 1 and 2; SRP, signal recognition particle; TIF1- $\gamma$, transcription intermediary factor 1 gamma.

\section{Competing interests}

The authors declare that they have no competing interests.

Published: 18 March 2011

\section{References}

1. Bohan A, Peter JB: Polymyositis and dermatomyositis (first of two parts). N Engl J Med 1975, 292:344-347.

2. Bohan A, Peter JB: Polymyositis and dermatomyositis (second of two parts). NEngl J Med 1975, 292:403-407.

3. Tanimoto K, Nakano K, Kano S, Mori S, Ueki H, Nishitani H, Sato T, Kiuchi T, Ohashi Y: Classification criteria for polymyositis and dermatomyositis. J Rheumatol 1995, 22:668-674.

4. Gunawardena H, Betteridge ZE, McHugh NJ: Myositis-specific autoantibodies: their clinical and pathogenic significance in disease expression. Rheumatology (Oxford) 2009, 48:607-612.

5. Chinoy H, Salway F, Fertig N, Shephard N, Tait BD, Thomson W, Isenberg DA, Oddis CV, Silman AJ, Ollier WE, Cooper RG; UK Adult Onset Myositis Immunogenetic Collaboration (AOMIC): In adult onset myositis, the presence of interstitial lung disease and myositis specific/associated antibodies are governed by HLA class II haplotype, rather than by myositis subtype. Arthritis Res Ther 2006, 8:R13.

6. Vancsa A, Gergely L, Ponyi A, Lakos G, Nemeth J, Szodoray P, Danko K: Myositis-specific and myositis-associated antibodies in overlap myositis in comparison to primary dermatopolymyositis: relevance for clinical classification: retrospective study of 169 patients. Joint Bone Spine 2010, 77:125-130.

7. Rider LG, Miller FW, Targoff IN, Sherry DD, Samayoa E, Lindahl M, Wener MH, Pachman LM, Plotz PH: A broadened spectrum of juvenile myositis. Myositis-specific autoantibodies in children. Arthritis Rheum 1994, 37:1534-1538.
8. Yoshifuji H, Fujii T, Kobayashi S, Imura Y, Fujita Y, Kawabata D, Usui T, Tanaka M, Nagai S, Umehara H, Mimori T: Anti-aminoacyl-tRNA synthetase antibodies in clinical course prediction of interstitial lung disease complicated with idiopathic inflammatory myopathies. Autoimmunity 2006, 39:233-241.

9. Stone KB, Oddis CV, Fertig N, Katsumata Y, Lucas M, Vogt M, Domsic R, Ascherman DP: Anti-Jo-1 antibody levels correlate with disease activity in idiopathic inflammatory myopathy. Arthritis Rheum 2007, 56:3125-3131.

10. Schmidt WA, Wetzel W, Friedlander R, Lange R, Sorensen HF, Lichey HJ, Genth E, Mierau R, Gromnica-Ihle E: Clinical and serological aspects of patients with anti-Jo-1 antibodies--an evolving spectrum of disease manifestations. Clin Rheumatol 2000, 19:371-377.

11. Hirakata M, Suwa A, Takada T, Sato S, Nagai S, Genth E, Song YW, Mimori T, Targoff IN: Clinical and immunogenetic features of patients with autoantibodies to asparaginyl-transfer RNA synthetase. Arthritis Rheum 2007, 56:1295-1303.

12. Matsushita T, Hasegawa M, Fujimoto M, Hamaguchi Y, Komura K, Hirano T, Horikawa M, Kondo M, Orito H, Kaji K, Saito Y, Matsushita Y, Kawara S, Yasui M, Seishima M, Ozaki S, Kuwana M, Ogawa F, Sato S, Takehara K: Clinical evaluation of anti-aminoacyl tRNA synthetase antibodies in Japanese patients with dermatomyositis. J Rheumato/ 2007, 34:1012-1018.

13. Sato S, Kuwana M, Hirakata M: Clinical characteristics of Japanese patients with anti-OJ (anti-isoleucyl-tRNA synthetase) autoantibodies. Rheumatology (Oxford) 2007, 46:842-845.

14. Yamasaki Y, Yamada H, Nozaki T, Akaogi J, Nichols C, Lyons R, Loy AC, Chan EK, Reeves WH, Satoh M: Unusually high frequency of autoantibodies to PL-7 associated with milder muscle disease in Japanese patients with polymyositis/dermatomyositis. Arthritis Rheum 2006, 54:2004-2009.

15. Hashish L, Trieu EP, Sadanandan P, Targoff IN: Identification of autoantibodies to tyrosyl-tRNA synthetase in dermatomyositis with features consistent with antisynthetase syndrome (abstract). Arthritis Rheum 2005, 52:S312.

16. Betteridge Z, Gunawardena H, North J, Slinn J, McHugh N: Anti-synthetase syndrome: a new autoantibody to phenylalanyl transfer RNA synthetase (anti-Zo) associated with polymyositis and interstitial pneumonia. Rheumatology (Oxford) 2007, 46:1005-1008.

17. Casciola-Rosen L, Nagaraju K, Plotz P, Wang K, Levine S, Gabrielson E, Corse A, Rosen A: Enhanced autoantigen expression in regenerating muscle cells in idiopathic inflammatory myopathy. J Exp Med 2005, 201:591-601.

18. Casciola-Rosen L, Andrade F, Ulanet D, Wong WB, Rosen A: Cleavage by granzyme $B$ is strongly predictive of autoantigen status: implications for initiation of autoimmunity. J Exp Med 1999, 190:815-826.

19. Levine SM, Raben N, Xie D, Askin FB, Tuder R, Mullins M, Rosen A, CasciolaRosen LA: Novel conformation of histidyl-transfer RNA synthetase in the lung: the target tissue in Jo-1 autoantibody-associated myositis. Arthritis Rheum 2007, 56:2729-2739.

20. Howard OM, Dong HF, Yang D, Raben N, Nagaraju K, Rosen A, Casciola-Rosen L, Härtlein M, Kron M, Yang D, Yiadom K, Dwivedi S, Plotz PH, Oppenheim JJ: Histidyl-tRNA synthetase and asparaginyl-tRNA synthetase, autoantigens in myositis, activate chemokine receptors on T lymphocytes and immature dendritic cells. J Exp Med 2002, 196:781-791.

21. Barbasso Helmers S, Englund P, Engström M, Ahlin E, Fathi M, Janciauskiene $S$, Heimbürger M, Rönnelid J, Lundberg IE: Sera from anti-Jo-1-positive patients with polymyositis and interstitial lung disease induce expression of intercellular adhesion molecule 1 in human lung endothelial cells. Arthritis Rheum 2009, 60:2524-2530.

22. Eloranta ML, Barbasso HS, Ulfgren AK, Ronnblom L, Alm GV, Lundberg IE: A possible mechanism for endogenous activation of the type I interferon system in myositis patients with anti-Jo-1 or anti-Ro 52/anti-Ro 60 autoantibodies. Arthritis Rheum 2007, 56:3112-3124.

23. Targoff IN, Reichlin $\mathrm{M}$ : The association between $\mathrm{Mi}-2$ antibodies and dermatomyositis. Arthritis Rheum 1985, 28:796-803.

24. Feldman BM, Reichlin M, Laxer RM, Targoff IN, Stein LD, Silverman ED: Clinical significance of specific autoantibodies in juvenile dermatomyositis. J Rheumatol 1996, 23:1794-1797.

25. Wedderburn LR, McHugh NJ, Chinoy H, Cooper RG, Salway F, Ollier WE, McCann LJ, Varsani H, Dunphy J, North J, Davidson JE; Juvenile Dermatomyositis Research Group (JDRG): HLA class II haplotype and autoantibody associations in children with juvenile dermatomyositis and juvenile dermatomyositis-scleroderma overlap. Rheumatology (Oxford) 2007, 46:1786-1791.

26. Love LA, Weinberg CR, McConnaughey DR, Oddis CV, Medsger TA Jr., Reveille $J D$, Arnett FC, Targoff IN, Miller FW: Ultraviolet radiation intensity predicts 
the relative distribution of dermatomyositis and anti-Mi-2 autoantibodies in women. Arthritis Rheum 2009, 60:2499-2504.

27. Burd CJ, Kinyamu HK, Miller FW, Archer TK: UV radiation regulates Mi-2 through protein translation and stability. J Biol Chem 2008, 283:34976-34982.

28. Wang HB, Zhang Y: Mi2, an auto-antigen for dermatomyositis, is an ATPdependent nucleosome remodeling factor. Nucleic Acids Res 2001, 29:2517-2521

29. Mammen AL, Casciola-Rosen LA, Hall JC, Christopher-Stine L, Corse AM, Rosen A: Expression of the dermatomyositis autoantigen Mi-2 in regenerating muscle. Arthritis Rheum 2009, 60:3784-3793.

30. Kashiwagi M, Morgan BA, Georgopoulos K: The chromatin remodeler Mi-2beta is required for establishment of the basal epidermis and normal differentiation of its progeny. Development 2007, 134:1571-1582.

31. Targoff IN, Mamyrova G, Trieu EP, Perurena O, Koneru B, O'Hanlon TP, Miller FW, Rider LG: A novel autoantibody to a $155-\mathrm{kd}$ protein is associated with dermatomyositis. Arthritis Rheum 2006, 54:3682-3689.

32. Kaji K, Fujimoto M, Hasegawa M, Kondo M, Saito Y, Komura K, Matsushita T, Orito H, Hamaguchi Y, Yanaba K, Itoh M, Asano Y, Seishima M, Ogawa F, Sato S, Takehara K: Identification of a novel autoantibody reactive with 155 and $140 \mathrm{kDa}$ nuclear proteins in patients with dermatomyositis: an association with malignancy. Rheumatology (Oxford) 2007, 46:25-28.

33. Chinoy H, Fertig N, Oddis CV, Ollier WE, Cooper RG: The diagnostic utility of myositis autoantibody testing for predicting the risk of cancer-associated myositis. Ann Rheum Dis 2007, 66:1345-1349.

34. Selva-O'Callaghan A, Trallero-Araguás E, Grau-Junyent JM, Labrador-Horrillo M: Malignancy and myositis: novel autoantibodies and new insights. Curr Opin Rheumatol 2010, 22:627-632.

35. Gunawardena H, North J, Wedderburn L, Davidson J, Betteridge ZE, Dunphy J, Chinoy H, Cooper RG, McHugh NJ: Clinical associations of anti-p155/140 autoantibodies in adult and juvenile dermatomyositis (abstract). Ann Rheum Dis 2007, 66:S68.

36. Espada G, Maldonado Cocco JA, Fertig N, Oddis CV: Clinical and serologic characterization of an argentine pediatric myositis cohort: identification of a novel autoantibody (anti-MJ) to a 142-kDa protein. J Rheumatol 2009, 36:2547-2551.

37. Targoff IN, Trieu EP, Levy-Neto M, Prasertsuntarsai T, Miller FW: Autoantibodies to transcriptional intermediary factor 1-gamma (TIF1-g) in dermatomyositis (abstract). Arthritis Rheum 2006, 54:S518.

38. Dupont S, Mamidi A, Cordenonsi M, Montagner M, Zacchigna L, Adorno M, Martello G, Stinchfield MJ, Soligo S, Morsut L, Inui M, Moro S, Modena N, Argenton F, Newfeld SJ, Piccolo S: FAM/USP9x, a deubiquitinating enzyme essential for TGFbeta signaling, controls Smad4 monoubiquitination. Cell 2009, 136:123-135

39. Hoshino K, Muro Y, Sugiura K, Tomita Y, Nakashima R, Mimori T: Anti-MDA5 and anti-TIF1-gamma antibodies have clinical significance for patients with dermatomyositis. Rheumatology (Oxford) 2010, 49:1726-1733.

40. Sato S, Hirakata M, Kuwana M, Suwa A, Inada S, Mimori T, Nishikawa T, Oddis CV, Ikeda Y: Autoantibodies to a 140-kd polypeptide, CADM-140, in Japanese patients with clinically amyopathic dermatomyositis. Arthritis Rheum 2005, 52:1571-1576.

41. Sato S, Hoshino K, Satoh T, Fujita T, Kawakami Y, Kuwana M: RNA helicase encoded by melanoma differentiation-associated gene 5 is a major autoantigen in patients with clinically amyopathic dermatomyositis: association with rapidly progressive interstitial lung disease. Arthritis Rheum 2009, 60:2193-2200.

42. Nakashima R, Imura Y, Kobayashi S, Yukawa N, Yoshifuji H, Nojima T, Kawabata D, Ohmura K, Usui T, Fujii T, Okawa K, Mimori T: The RIG-I-like receptor IFIH1/ MDA5 is a dermatomyositis-specific autoantigen identified by the antiCADM-140 antibody. Rheumatology (Oxford) 2010, 49:433-440.

43. Fujikawa K, Kawakami A, Kaji K, Fujimoto M, Kawashiri S, Iwamoto N, Aramaki T, Ichinose K, Tamai M, Kamachi M, Nakamura H, Ida H, Oriquchi T, Ishimoto H, Mukae H, Kuwana M, Kohno S, Takehara K, Sato S, Eguchi K: Association of distinct clinical subsets with myositis-specific autoantibodies towards anti-155/140-kDa polypeptides, anti-140-kDa polypeptides, and antiaminoacyl tRNA synthetases in Japanese patients with dermatomyositis: a single-centre, cross-sectional study. Scand J Rheumatol 2009, 38:263-267.
44. Oddis CV, Fertig N, Goel A, Espada G, Confalone Gregorian M, Maldonado Cocco MA: Clinical and serological characterisation of the anti-M J antibody in childhood myositis (abstract). Arthritis Rheum 1997, 40:5139.

45. Targoff IN, Trieu EP, Levy-Neto M, Fertig N, Oddis CV: Sera with autoantibodies to the MJ antigen react with NXP2. Arthritis Rheum 2007, 56:5787.

46. Kimura Y, Sakai F, Nakano O, Kisaki O, Sugimoto H, Sawamura T, Sadano H, Osumi T: The newly identified human nuclear protein NXP-2 possesses three distinct domains, the nuclear matrix-binding, RNA-binding, and coiled-coil domains. J Biol Chem 2002, 277:2061 1-20617.

47. Gunawardena H, Wedderburn LR, Chinoy H, Betteridge ZE, North J, Ollier WE, Cooper RG, Oddis CV, Ramanan AV, Davidson JE, McHugh NJ; Juvenile Dermatomyositis Research Group, UK and Ireland: Autoantibodies to a 140-kd protein in juvenile dermatomyositis are associated with calcinosis. Arthritis Rheum 2009, 60:1807-1814.

48. Betteridge ZE, Gunawardena H, Chinoy H, Vencovsky J, Allard S, Gordon PA, Cooper RG, McHugh NJ: Clinical associations of anti-p140 autoantibodies in adult myositis. Ann Rheum Dis 2010, 69 (Suppl 3):127.

49. Betteridge Z, Gunawardena H, North J, Slinn J, McHugh N: Identification of a novel autoantibody directed against small ubiquitin-like modifier activating enzyme in dermatomyositis. Arthritis Rheum 2007, 56:3132-3137.

50. Betteridge ZE, Gunawardena H, Chinoy H, North J, Ollier WE, Cooper RG McHugh NJ; UK Adult Onset Myositis Immunogenetic Collaboration: Clinical and HLA-class II haplotype associations of autoantibodies to small ubiquitin-like modifier enzyme, a dermatomyositis-specific autoantigen target, in UK adult-onset Caucasian myositis. Ann Rheum Dis 2009, 68:1621-1625.

51. Reeves WH, Nigam SK, Blobel G: Human autoantibodies reactive with the signal-recognition particle. Proc Natl Acad SciU S A 1986, 83:9507-9511.

52. Targoff IN, Johnson AE, Miller FW: Antibody to signal recognition particle in polymyositis. Arthritis Rheum 1990, 33:1361-1370.

53. Hengstman GJ, ter Laak HJ, Vree Egberts WT, Lundberg IE, Moutsopoulos HM, Vencovsky J, Doria A, Mosca M, van Venrooij WJ, van Engelen BG: Anti-signal recognition particle autoantibodies: marker of a necrotising myopathy. Ann Rheum Dis 2006, 65:1635-1638.

54. Miller T, Al-Lozi MT, Lopate G, Pestronk A: Myopathy with antibodies to the signal recognition particle: clinical and pathological features. $J$ Neurol Neurosurg Psychiatry 2002, 73:420-428.

55. Brouwer R, Hengstman GJ, Vree Egberts W, Ehrfeld H, Bozic B, Ghirardello A, Grøndal G, Hietarinta M, Isenberg D, Kalden JR, Lundberg I, Moutsopoulos H, Roux-Lombard P, Vencovsky J, Wikman A, Seelig HP, van Engelen BG, van Venrooij WJ: Autoantibody profiles in the sera of European patients with myositis. Ann Rheum Dis 2001, 60:116-123.

56. Rouster-Stevens KA, Pachman LM: Autoantibody to signal recognition particle in African American girls with juvenile polymyositis. $J$ Rheumatol 2008, 35:927-929.

57. Christopher-Stine L, Casciola-Rosen LA, Hong G, Chung T, Corse AM, Mammen AL: A novel autoantibody recognizing 200-kd and 100-kd proteins is associated with an immune-mediated necrotizing myopathy. Arthritis Rheum 2010, 62:2757-2766.

58. Ghirardello A, Rampudda M, Ekholm L, Bassi N, Tarricone E, Zampieri S, Zen M, Vattemi GA, Lundberg IE, Doria A: Diagnostic performance and validation of autoantibody testing in myositis by a commercial line blot assay. Rheumatology (Oxford) 2010, 49:2370-2374.

59. Vencovsky J, Lundberg IE, Patterson E, Ekholm L, Dankø K, Putova I, Charles PJ: Myositis associated autoantibodies detected using a novel recombinant protein blotting: clinical associations. Ann Rheum Dis 2010, 69 (Suppl 3):425.

\section{doi:10.1186/ar3275}

Cite this article as: Betteridge ZE, et al:: Novel autoantibodies and clinical phenotypes in adult and juvenile myositis. Arthritis Research \& Therapy 2011, 13:209. 